\title{
DNA methylation: a secondary event in globin gene switching?
}

\author{
Tariq Enver, ${ }^{1}$ Jun-wu Zhang, Thalia Papayannopoulou, ${ }^{2}$ and George Stamatoyannopoulos \\ Divisions of Medical Genetics and ${ }^{2}$ Hematology, Department of Medicine, University of Washington, Seattle, Washington \\ 98195 USA
}

Changes in $\gamma$-globin gene methylation accompany the fetal to adult globin switch in man. Using somatic cell hybrids made by fusing mouse erythroleukemia and human fetal erythroid cells, we asked whether methylation is a cause or a consequence of $\boldsymbol{\gamma}$-gene inactivation during development. These hybrids initially express human $\gamma$-globin but switch with time in culture to adult globin gene production. In hybrids before the switch, the $\gamma$ genes are unmethylated. After completion of the switch, the hybrids contain methylated $\gamma$-globin genes.

However, during the time that the $\gamma \rightarrow \beta$ switch is occurring, hybrids are found that no longer express $\gamma$-globin, yet still possess unmethylated $\gamma$-globin genes. This suggests that methylation is not a primary event in $\gamma$-gene inactivation during human development.

[Key Words: DNA methylation; globin gene switching; somatic cell hybrids; fetal globin; MEL cells]

Received February 16, 1988; revised version accepted April 21, 1988.

Methylation of the cytosine residue to produce 5-methylcytosine is the only known genetically programmed covalent modification of the DNA of higher eukaryotes (see Razin 1984). In trying to establish a role for 5-methylcytosine, the major focus has been on the relationship between methylation and transcriptional regulation. Through the use of methylation-sensitive restriction endonucleases, the methylation status of specific sites in or about given genes in various tissues has been documented and related to their transcriptional status. The globin gene families of the vertebrates have been widely exploited as model systems for studies of this nature (Waalwijk and Flavell 1978; McGhee and Ginder 1979; Shen and Maniatis 1980; van der Ploeg and Flavell 1980; Mavilio et al. 1983). From these studies, two basic classes of sites emerge: those that are methylated to the same degree in all tissues and those that are variably methylated with respect to tissue type. For the most part, this variability takes the form of undermethylation in expressing tissues. Unfortunately, studies of this type give no information as to cause or effect. Hypomethylation of these positions could be critical for the transcriptional activity of a gene or may be a consequence of transcription inhibiting the methylation process.

In attempting to resolve the cause-effect dilemma, two approaches have been widespread. One has focused on using drugs [5-azacytidine (Jones and Taylor 1980), L-ethionine (Christman et al. 1977; Boehm and Drahovsky 1981), etc.], which result in a ubiquitous undermethylation of the genome. The other involves methylating specific genes in vitro and then either testing them in in vitro transcription systems (Shen 1984) or introducing them by reverse genetics into eukaryotic cells (Busslinger et al. 1983; Murray and Grosveld 1987). Both

${ }^{2}$ Corresponding author. approaches demonstrate that changes in DNA methylation may have profound effects on gene expression. Whether the methylation changes induced by these methods, however, are physiologically or developmentally relevant remains unclear.

A potentially more illuminating approach to the cause-effect issue is to establish precisely the chronological order in which transcriptional silencing and DNA methylation occur. If gene inactivation were found to precede DNA methylation, this would imply that DNA methylation was a consequence of gene inactivation, i.e., that the transcriptional activity of the genes dictates the methylation pattern, rather than vice versa.

We have addressed this question using the human $\beta$ globin gene cluster as a model. The developing human progressively switches from embryonic $\langle\epsilon|$, to fetal $\gamma$ and, finally, to adult $\beta$-globin synthesis (Stamatoyannopoulos and Nienhuis 1987). In the preswitch erythroid cells of the fetal liver, the $\gamma$-genes are transcriptionally active and unmethylated. In the postswitch erythroid cells of the adult bone marrow where they are transcriptionally quiescent, they are methylated (Mavilio et al. 1983). To establish the chronological order in which transcriptional silencing and DNA methylation of the $\gamma$-genes occur, one needs to monitor the methylation/ expression relationship of cells carefully at the time the $\gamma \rightarrow \beta$ switch is occurring. This developmental switch begins toward the end of the second trimester of human development (24-30 weeks) and is not complete until a few months after birth (Wood et al. 1977). A limited amount of material for the study of hematopoietic development is available, with maternal consent as a result of abortions that may be performed up to 20 weeks of gestation (Shepard et al. 1988). With the exception of spontaneous abortions, human development must obligatorily remain a closed book beyond this point. We have 
reconstituted the $\gamma \rightarrow \beta$ switch in vitro using heterospecific synkaryons formed by fusing human fetal erythroblasts (HFE) with mouse erythroleukemia (MEL) cells (Papayannopoulou et al. 1986). These synkaryons initially express human $\gamma$-globin but switch to $\beta$-globin production in culture at a rate roughly dependent on the developmental age of the fetuses used. These hybrids provide theoretically unlimited numbers of pure erythroid cells throughout the switching period. We have used this model system to study the role of DNA methylation in the developmental regulation of gene expression.

\section{Results}

\section{Experimental system}

Fetal erythroblasts were obtained from first trimester human abortuses. At this stage of development, the liver is primarily an erythropoietic organ, and the fetal erythroid cells produce mainly $\gamma$-globin, as well as small amounts of $\beta$-globin (Weatherall and Clegg 1981). These $\gamma$-expressing HFE cells were fused with MEL cells that express the adult program of mouse globin gene expression. The HFE $\times$ MEL hybrids initially express a fetal program of human globin gene expression (i.e., mainly $\gamma^{+}$with few $\beta^{+}$cells) (Fig. 1, panel A). However, with increasing time in culture, these hybrids begin to switch from $\gamma$ to $\beta$-globin production. At the cellular level, this is seen as a decrease in the number of $\gamma^{+}$cells, with a concomitant increase in the number of $\beta^{+}$cells. A typical hybrid at the time of switching is shown in Figure 1, panel B. It is composed of roughly equivalent numbers of $\gamma^{+}$and $\beta^{+}$cells, as well as rare cells that coexpress $\gamma$ and $\beta$-globin. Upon completion of the switch, the hybrids express an adult program of human globin gene expression, i.e., mainly $\beta$-globin (Fig. 1, panel C). We used these somatic cell hybrids from across the developmental spectrum (i.e., preswitch, switching, switched) to analyze the relationship between DNA methylation and $\gamma$-globin gene expression during ontogeny.

$\gamma$-Globin gene methylation is developmentally regulated in HFE $\times$ MEL hybrids

The methylation status of the $\gamma$-globin genes may be assessed using the methylation-sensitive restriction endonuclease HpaII. Of the potential methylation sites within the $\beta$-like globin gene cluster amenable to analysis with HpaIl, the methylation status of three, namely, $\gamma^{2}, \gamma^{4}$, and $\gamma^{6}$, shows a good correlation with fetal globin gene expression (van der Ploeg and Flavell 1980; Mavilio et al. 1983). $\gamma^{2}$ and $\gamma^{4}$ lie roughly $50 \mathrm{bp}$ upstream from the ${ }^{\mathrm{G}} \gamma$ and ${ }^{\mathrm{A}} \gamma$ cap sites, respectively, whereas $\gamma^{6}$ is located $\sim 230$ bp downstream of the ${ }^{A} \gamma$ polyadenylation signal (Shen et al. 1981), just upstream of a recently identified enhancerlike sequence (Bodine and Ley 1987|. These positions are unmethylated when the fetal globin genes are transcriptionally active and methylated when they are quiescent.
Using BamHI-HpaII complex digestions, we analyzed the methylation status of these positions in preswitch fetal liver $\times$ MEL somatic cell hybrids expressing the fetal program of human globin gene expression (Table 1, Fig. 2A) and in hybrids that completed the $\gamma \rightarrow \beta$ switch in culture and were expressing an adult globin gene program (Table 1, Fig. 2B). BamHI digestion yields three $\gamma$ globin gene-containing fragments of $14.5,5.0$, and $2.7 \mathrm{~kb}$ (Fig. 2A, lane 3). In the preswitch, $\gamma$-expressing hybrids (Fig. 2A, lanes 1,2), $\gamma^{2}, \gamma^{4}$, and $\gamma^{6}$, are completely cleaved by HpaII. This cleavage at $\gamma^{4}$ results in the generation of a $4.5-\mathrm{kb}$ band from the $5.0-\mathrm{kb}$ fragment. Cleavage of the $14.5-\mathrm{kb}$ BamHI fragment at $\gamma^{6}$ produces a $1.3-\mathrm{kb}$ fragment, and HpaII restriction of $\gamma^{2}$ results in the disappearance of the $2.7-\mathrm{kb} \mathrm{BamHI}$ fragment. In hybrids that have completed the $\gamma \rightarrow \beta$ switch in culture, these sites are methylated. DNA methylation at $\gamma^{2}$ and $\gamma^{4}$ results in the failure of $\mathrm{HpaII}$ cleavage and, thus, the persistence of the 2.7- and 5.0-kb fragments (Fig. 2B, lanes 1,2). Similarly, the $14.5-\mathrm{kb}$ fragment is not cleaved at $\gamma^{6}$ by HpaII to generate a $1.3-\mathrm{kb}$ band. It is, however, cleaved at $\gamma^{7}$, producing a $2.1-\mathrm{kb}$ band. The methylation of this site shows no developmental or tissue specificity and is unmethylated in all somatic cells. It appears that the hybrids are no exception.

These data demonstrate that methylation at these positions $\left(\gamma^{2}, \gamma^{4}, \gamma^{6}\right)$ correlates with $\gamma$-globin gene expression in these somatic cell hybrids, the $\gamma$-genes being unmethylated when expressed and methylated when quiescent.

\section{Switching precedes methylation}

If methylation does not play a primary role in switching, one would expect cells that have just switched and are no longer expressing $\gamma$-globin to still be unmethylated in the $\gamma$-gene region. Locating a population of cells that have just switched is not straightforward because the $\gamma \rightarrow \beta$ switch is not synchronized at the cellular level. Thus, at any given moment during the switching period, the cellular population is heterogeneous with respect to globin phenotype (Papayannopoulou et al. 1986), being composed of cells that have not yet switched $\left(\gamma^{+}\right)$, rare cells in the actual process of switching $\left(\gamma^{+} \beta^{+}\right)$, and cells that have switched $\left(\beta^{+}\right)$. This $\left(\beta^{+}\right)$population is presumably heterogeneous itself, in that some of the cells have probably just switched, whereas others may have switched some time ago. However, in the case of the somatic cell hybrids, it is possible to capture and amplify the individual globin phenotypes that together constitute the heterogeneous switching population through cell subcloning (see Fig. 3). Subclones of a switching hybrid were obtained using a cell sorter that deposits single cells into individual wells. Human globin expression was assessed in these hybrid subclones after chemical induction by labeling with $\gamma$ - and $\beta$-specific monoclonal antibodies (Stamatoyannopoulos et al. 1983) (see Table 2 ). The presence of $y$-globin mRNA was also assessed in selected subclones by nuclease S1 mapping (Fig. 4). Three types of subclones were obtained (see Fig. 3; Table 
2): those that expressed a fetal program of human globin gene expression (preswitch or fetal phenotype), those that expressed an adult program (switched or adult phenotype), and those that resembled the parental population used in subcloning, i.e., were composed of fetal and adult phenotype cells in proportions observed during the $\gamma \rightarrow \beta$ switch in vivo (switching phenotype).

The status of DNA methylation at the developmentally regulated methylation positions $\gamma^{2}, \gamma^{4}$, and $\gamma^{6}$ was assessed in 'fetal phenotype' and 'switching phenotype' subclones, derived from a switching hybrid using HpaII (Fig. 5). HpaII cleavage at $\gamma^{2}$ and $\gamma^{4}$ generates a $5.0-\mathrm{kb}$ band, whereas cleavage at $\gamma^{4}$ and $\gamma^{6}$ yields a fragment of $1.8 \mathrm{~kb}$. Subclones with the fetal phenotype (Fig. 5, F1-F4) are unmethylated at $\gamma^{2}, \gamma^{4}$, and $\gamma^{6}$. Thus, at the time of switching, cells expressing the fetal program of globin gene expression have unmethylated $\gamma$-globin genes. Subclones with a switching phenotype also appear hypomethylated in the $\gamma$-gene region (Fig. 5, S1-S4), despite the fact that a large proportion of cells express the adult globin gene program, as judged by immunofluorescence.

Next, we analyzed the status of $\gamma$-gene methylation in 'adult phenotype' subclones [as judged by immunofluorescence (Table 2) and SI mapping (Fig. 4)] derived by the subcloning of the switching population. Figure 6 shows the analysis of $\gamma$-gene methylation in three adult phenotype subclones; examples of fetal (F2, F5) and switching (S4) phenotype subclones are included as controls. One adult phenotype subclone appears completely methyl-

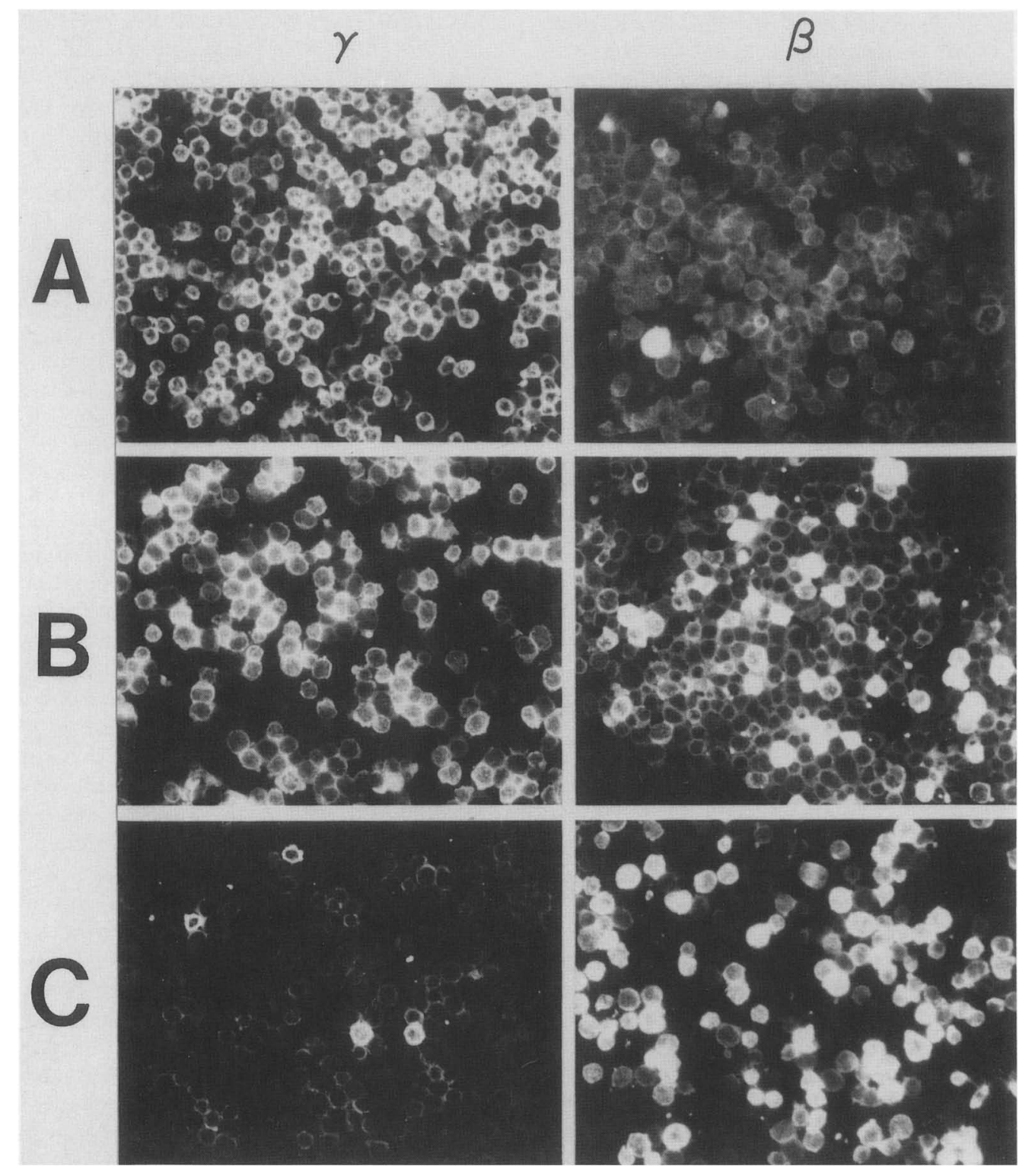

Figure 1. Globin gene switching in HFE $\times$ MEL hybrids. Labeling of induced hybrid cells from different stages of switching with either anti- $\gamma($ left) or anti- $\beta$ (right) monoclonal antibodies, followed by anti-mouse IgG-FITC: $(A)$ Preswitch; $(B)$ switching; $(C)$ postswitch. 

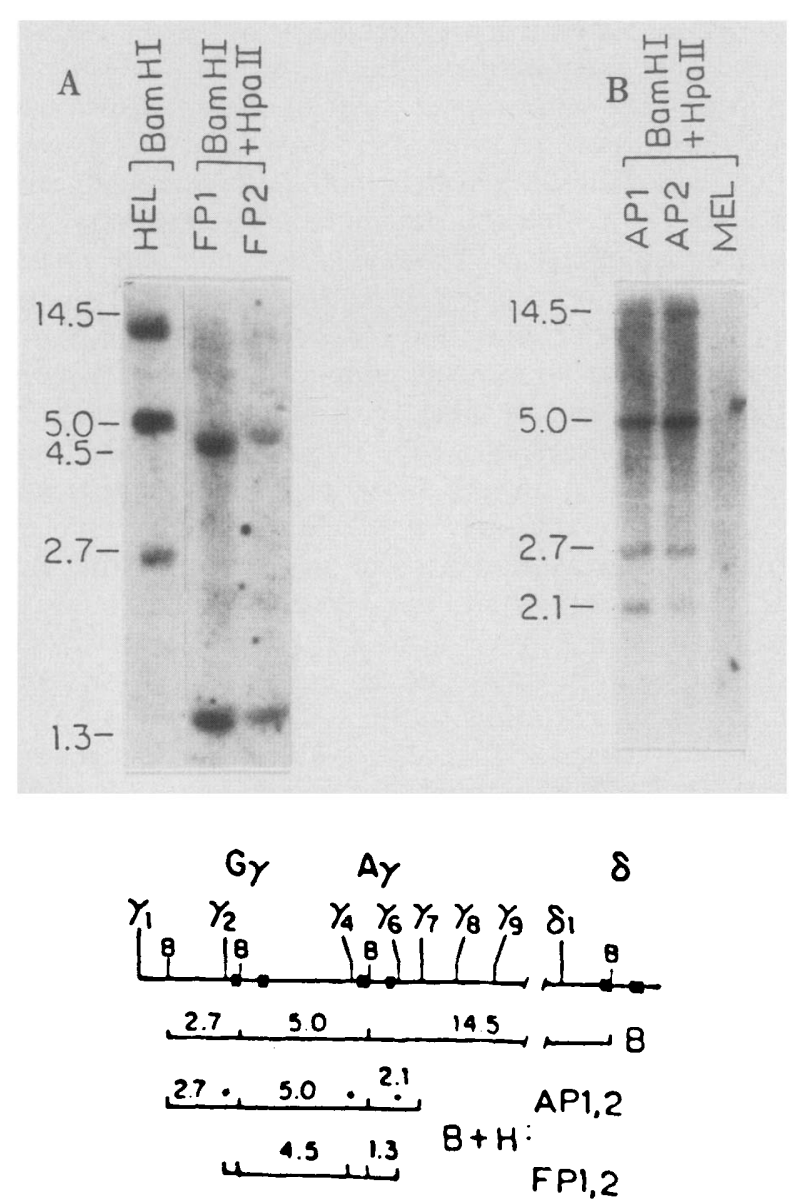

Figure 2. DNA methylation in HFE $\times$ MEL hybrids. DNAs prepared from fetal program hybrids (FP1, FP2) (panel $A$ ) and adult program hybrids (AP1, AP2) (panel $B$ ) were digested with BamHI and HpaII, blotted, and hybridized with a $\gamma$-region-specific probe. BamHI-digested human erythroleukemia cell (HEL) (panel $A$ ) and BamHI-HpaII-digested MEL cell DNA (panel $B$ ) are included as controls.

ated at $\gamma^{2}$ and $\gamma^{6}$ and, for the most part, at $\gamma^{4}$ (A2 in Fig. 6A). However, the other two adult phenotype subclones display the pattern of $\gamma$-globin gene DNA methylation characteristic of cells expressing the fetal globin gene program (A3 in Fig. 6A; A1 in Fig. 6B,C), i.e., are unmethylated at $\gamma^{2}, \gamma^{4}$, and $\gamma^{6}$. The finding of subclones in which the $\gamma$-genes have been switched off but remain unmethylated suggests that methylation is not the primary event in $\gamma$-gene inactivation during development.

\section{Discussion}

Somatic cell hybrids as a tool to study the developmental regulation of human globin gene switching

To study the mechanisms that underlie the developmental switches in globin gene expression, one needs to analyze nucleated cells from various stages of development. This is not straightforward in mammals, because nucleated erythroid cells are not present in the peripheral bloodstream. In humans, there is the further limitation that samples from the critical ontogenetic stages are not available for study.

By providing nucleated cells at various stages of human development, the HFE $\times$ MEL hybrids offer something of a solution to this problem. Because these hybrids undergo a fetal to adult globin gene switch, they allow one to follow the developmental fate of a single human chromosome. The rate at which the switch in culture occurs is largely dependent on the developmental age of the parental fetal erythroid cells used. Extensive cytogenetic and Southern blotting analyses have shown that the switching mechanism is syntenic to human chromosome 11 (Melis et al. 1987) (the chromosome that harbors the human $\beta$-like globin gene cluster). Thus, these hybrids demonstrate that switching can occur in cells of a single lineage, that the fetal chromosome is under the control of a developmental clock, and that this clock is linked to chromosome 11. As of yet, we do not know whether the clock operates in cis or in trans.

DNA methylation is one cis-acting modification of DNA long thought to play a role in gene regulation. We analyzed the relationship between methylation and expression during the course of development using the switching somatic cell hybrid system by analyzing the methylation status of specific $\gamma$-gene region, CpG dinucleotides, which fall within the recognition sequence of the methylation-sensitive restriction endonuclease Hpall. The CpG positions that we analyzed were chosen for two reasons. Firstly, because of their location: $\gamma^{2}$ and $\gamma^{4}$ are located at -54 of the ${ }^{\mathrm{G}} \boldsymbol{\gamma}$ - and ${ }^{\mathrm{A}} \gamma$-genes, respectively (i.e., within the promoter regions themselves). $\gamma^{6}$ is located at +1850 (i.e., within the $3^{\prime}$ flank of the ${ }^{\mathrm{A}} \gamma$ globin gene). Secondly, DNA methylation at sites correlates well with $\gamma$-gene expression. This relationship even extends to $\gamma$-gene expression in adult life. Activation of

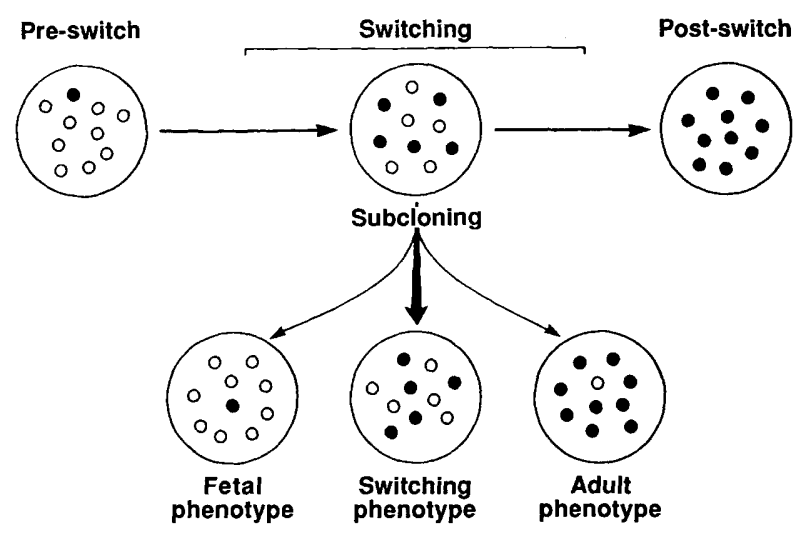

Figure 3. Subcloning of a switching HFE $\times$ MEL hybrid. $(0) \gamma^{+}$ cells; $\left(\bullet \beta^{+}\right.$cells. By producing 65 subclones from a switching hybrid, we generated 43 subclones with predominantly $\gamma^{+}$cells (fetal phenotype), 14 subclones with predominantly $\beta^{+}$cells (adult phenotype), and 8 subclones with both types of cells (switching phenotype). 
Enver et al.

Table 1. Globin gene expression in fetal and adult programmed HFE $\times$ MEL hybrids

\begin{tabular}{lccc}
\hline Hybrid & $\begin{array}{l}\text { Percent } \\
53 / 6^{+}\end{array}$ & $\begin{array}{l}\text { Percent } \\
\gamma^{+}\end{array}$ & $\begin{array}{l}\text { Percent } \\
\boldsymbol{\beta}^{+}\end{array}$ \\
\hline $\begin{array}{l}\text { Preswitch } \\
\text { FP1 }\end{array}$ & 70 & 50 & 5 \\
FP2 & 85 & 50 & 8 \\
Postswitch & & & 70 \\
AP1 & 90 & 0 & 75 \\
AP2 & 90 & 0 & \\
\hline
\end{tabular}

The number of hybrid cells containing human chromosome 11 was assessed by vital staining of hybrid cells with monoclonal antibody 53/6. The percentage of hybrid cells expressing $\gamma$ - or $\beta$-globin was assessed by staining induced cells with anti- $\gamma$ - and anti- $\beta$-specific monoclonal antibodies. The preswitch, fetal programmed hybrids are termed FP1 and FP2. The postswitch adult programmed hybrids are termed AP1 and AP2.

Table 2. Globin gene expression in hybrid subclones

\begin{tabular}{lccc}
\hline Hybrid & $\begin{array}{l}\text { Percent } \\
53 / 6^{+}\end{array}$ & $\begin{array}{l}\text { Percent } \\
\gamma^{+}\end{array}$ & $\begin{array}{l}\text { Percent } \\
\beta^{+}\end{array}$ \\
\hline $\begin{array}{l}\text { Parental hybrid } \\
\text { P }\end{array}$ & 90 & 53 & 24 \\
Fetal phenotype & 97 & 70 & 15 \\
F1 & 74 & 60 & 15 \\
F2 & 70 & 65 & 7 \\
F3 & 70 & 50 & 5 \\
F4 & 88 & 90 & 6 \\
F5 & & & \\
Switching phenotype & 84 & 10 & 25 \\
S1 & 80 & 25 & 10 \\
S2 & 86 & 12 & 44 \\
S3 & 90 & 40 & 39 \\
S4 & & & \\
Adult phenotype & 90 & 5 & 60 \\
A1 & 80 & 0 & 40 \\
A2 & 80 & 0 & 45 \\
A3 & & & \\
\hline
\end{tabular}

The percentage of $\gamma^{+}, \beta^{+}$, and human chromosome 11-containing hybrid cells in the parental hybrid $(\mathrm{P})$ and its fetal phenotype (F1-F5), switching phenotype (S1-S4), and adult phenotype subclones $(\mathrm{A} 1-\mathrm{A} 3)$ is shown. Methods are given in Table 1.

$\mathrm{HbF}$ in adult cells is accompanied by $\gamma$-gene undermethylation (Groudine et al. 1986). Furthermore, inhibition of reactivated $\mathrm{HbF}$ production by switching activities results in methylation of $\gamma$-gene HpaII sites /Groudine et al. 1986).

We find that preswitch hybrids expressing the $\gamma$-globin genes have unmethylated $\gamma$-globin genes. After the switch has been completed in culture, these hybrids have methylated $\gamma$-genes. Therefore, $\gamma$-gene methylation is developmentally regulated during the fetal to adult globin gene switch in somatic cell hybrids.

\section{DNA methylation is a secondary event in $\gamma$-gene inactivation}

The question as to whether methylation was a cause or an effect of switching was tackled by analyzing hybrids at the time of switching. These switching hybrids are heterogeneous with respect to globin gene expression at the cellular level, i.e., they are composed of $\gamma^{+}$, as well as $\beta^{+}$, cells. However, by subcloning a switching hybrid, we could overcome the problem of heterogeneity. We obtained three types of subclones: $\gamma^{+}$(fetal phenotype), $\beta^{+}$(adult phenotype), and $\gamma^{+}$and $\beta^{+}$(switching phenotypel. These subclones contain the same human chromosome, at the same developmental age, but with a different developmental phenotype. In essence, these subclones provide and allow one to study the $\gamma$-gene, just before switching, during switching, and just after the switch. In so doing, they provide an in vitro system in which time measurements can be made. We find that just before the switch, the $\gamma$-gene is unmethylated. During the switch, the $\gamma$-gene is also unmethylated. Just after the switch, the $\gamma$-gene is unmethylated in some subclones but not in others.

Based on these results, we suggest that the sequence of events in globin gene switching is as follows. Before the switch, the sites investigated are unmethylated in $\gamma$-expressing erythroid cells. Inactivation of the $\gamma$-genes occurs during switching. These sites in the inactive but unmethylated $\gamma$-genes are now targets for DNA methylation. By finding subclones that no longer express fetal hemoglobin yet remain unmethylated in the $\gamma$-globin region, we have provided an exception to the inverse correlation exhibited by DNA methylation at these positions and $\gamma$-globin gene expression. Thus, we propose that the transcriptional status of the gene dictates the methylation status of these positions, and not vice versa.

$\gamma$-Gene reactivation has been elicited by 5 -azacytidine treatment of fibroblast $\times$ MEL somatic cell hybrids (Ley et al. 1984). These hybrids normally express only adult

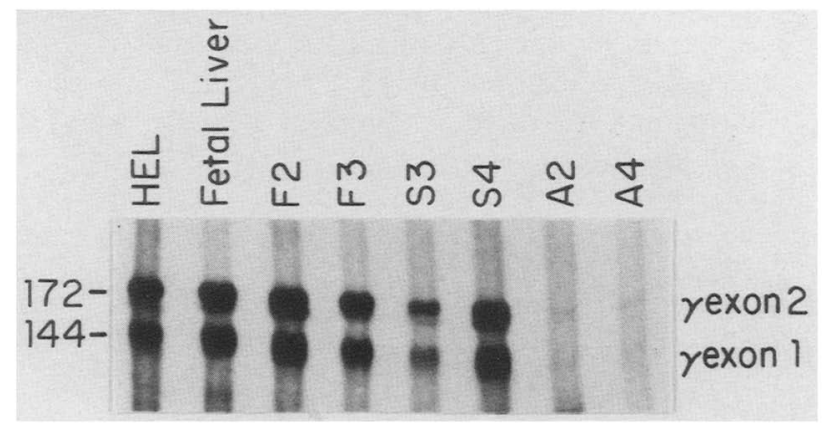

Figure 4. Nuclease S1 mapping of hybrid subclones. Ten micrograms of total cellular RNA from HEL cells, fetal liver cells, fetal phenotype (F2, F3), switching phenotype (S3, S4), and adult phenotype (A2, A4) hybrid subclones was hybridized to a $\gamma$-specific probe, digested with nuclease $\mathrm{S} 1$, and electrophoresed. The probe and its expected protection products are represented schematically in the diagram. 


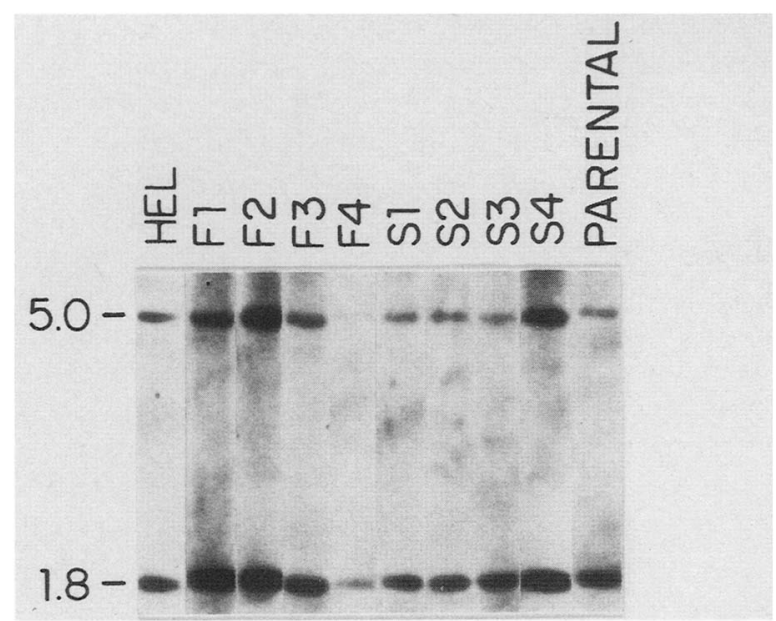

Figure 5. DNA methylation in fetal and switching phenotype subclones. HpaII-digested DNA from the parental hybrid and its fetal (F1, F4) and switching (S1, S4) phenotype subclones, and from a HEL cell control was electrophoresed, blotted, and probed with a labeled $\gamma$-gene fragment. A schematic interpretation of the digestion patterns is provided.

globins. However, low levels of $\gamma$-globin gene transcription (21 copies per cell) can be observed after treatment with 5 -azacytidine. This compares to the 2500 copies per cell of $\gamma$-globin mRNA observed in the fetal liver $\times$ MEL hybrids studied here. This low-level stimulation of $\gamma$-globin gene transcription seen after treatment with 5-azacytidine is consistent with the idea that DNA methylation serves as a secondary, as opposed to primary, gene-silencing system for $\gamma$-globin. Interestingly, 5 -azacytidine treatment of switched fetal liver $\times$ MEL hybrids producing only $\beta$-globin does not result in obvious $\gamma$-gene reactivation, as judged by immunofluorescence and isoelectric focusing of labeled globin chains (T. Papayannopoulou et al., unpubl.). This does not rule out the possibility that low levels of $\gamma$-transcription have been induced.

It has been shown recently that the inactivation of a housekeeping (HPRT) gene precedes its methylation during X chromosome inactivation (Lock et al. 1987). A similar conclusion has been reached in a study of the inactivation of a retrovirus (Moloney murine leukemia virus) after infection of murine teratocarcinoma cells (Niwa et al. 1983). We have shown that methylation follows the inactivation of a tissue-specific, developmentally regulated, cellular gene ( $\gamma$-globin). Thus, it would seem that methylation is acting as a secondary, rather than primary, gene-silencing system, serving to 'lock in' a pattern of inactivity established by some other mechanism (Razin and Riggs 1980; Riggs 1984; Gartler et al. 1985; Monk 1986).

\section{Materials and methods}

\section{Cellular procedures}

The production, subcloning, induction, and antibody staining of HFE $\times$ MEL hybrids has been described in detail (Papayannopoulou et al. 1986). Briefly, 70-day-old fetal liver cells obtained from human abortuses were fused with APRT-deficient mouse erythroleukemia cells (Deisseroth and Hendrick 1979), using polyethylene glycol. Hybrids retaining the human $\beta$-like globin gene cluster were identified using a monoclonal antibody (53/6) (Papayannopoulou et al. 1986) directed against a human chromosome 11 -encoded constitutively expressed cellsurface antigen. These $53 / 6^{+}$cells were enriched by immunoadherence (Wysocki and Sato 1978) (panning) or fluorescenceactivated cell sorting (FACS). Cell subcloning was performed by fluorescent single cell sorting of $53 / 6^{+}$cells into individual wells. Globin chain expression in hybrids and hybrid subclones was assessed after hybrids were induced with $4 \mathrm{~mm}$ HMBA (hexamethylenebisacetamide) for 3 days. Cytocentrifuge-prepared cellular spreads were fixed with methanol and washed with PBS first and then water, prior to drying and incubation with either $\gamma$ - or $\beta$-specific monoclonal antibodies at $37^{\circ} \mathrm{C}$ (Stamatoyannopoulos et al. 1983). Following a second cycle of washing, the preparations were incubated with a FITC-conjugated goat anti-mouse IgG $\left[\mathrm{F}\left(\mathrm{ab}^{\prime}\right)_{2}\right]$ antibody.

\section{Preparation of RNA and nuclease S1 analysis}

Total cellular RNA was prepared from $2-5 \times 10^{7}$ cells by lysis in $4 \mathrm{M}$ guanidine hydrochloride, followed by cesium chloride gradient $(2 \mathrm{~g} / \mathrm{ml}$ ) centrifugation at $32 \mathrm{~K}$ for $40 \mathrm{hr}$ (Kantor et al. 1980). The RNA pellet was dissolved in $2 \mathrm{ml}$ of NETS buffer $(100 \mathrm{~mm} \mathrm{NaCl}, 10 \mathrm{~mm}$ Tris-HCl (pH 7.5), $1.0 \mathrm{~mm}$ EDTA, and $1.0 \% \mathrm{SDS}$ ) and, following phenol extraction, was precipitated twice in ethanol and stored at $-70^{\circ} \mathrm{C}$. After centrifugation, the RNA was dissolved in water and used for subsequent analysis. A uniformly labeled M13mp7 probe was prepared, as described in detail previously (Ley et al. 1982). Total cellular RNA (2-20 $\mu \mathrm{g}$ ) was annealed with $30-70,000 \mathrm{cpm}$ of probe for $3 \mathrm{hr}$ at $52^{\circ} \mathrm{C}$ in $10 \mu \mathrm{l}$ reaction mixture containing $80 \%$ formamide (vol/vol), $40 \mathrm{~mm}$ PIPES buffer (pH 6.4), $400 \mathrm{mM} \mathrm{NaCl}$, and $1 \mathrm{~mm}$ EDTA (Favaloro et al. 1980). Each hybridization reaction mixture was then digested with 60 units of nuclease $S 1$ (Sigma) at $37^{\circ} \mathrm{C}$ for $30 \mathrm{~min}$, and the nuclease-S1-resistant hybrids were precipitated with ethanol and analyzed by electrophoresis in denaturing polyacrylamide sequencing gels (Favaloro et al. 1980).

\section{DNA preparation and analysis}

High-molecular-weight DNA was prepared, essentially as described by Maniatis et al. (1982); however, after chloroform extraction, DNA was recovered by ethanol precipitation, as opposed to dialysis. DNA aliquots of $15 \mu \mathrm{g}$ were digested with restriction endonucleases for $12 \mathrm{hr}$, according to the manufacturers' recommendations. One tenth of the reaction mixture was then removed, and $0.5 \mu \mathrm{g}$ of $\lambda$ DNA added to it, followed by further incubation for $1 \mathrm{hr}$. Complete cleavage of $\lambda$ DNA in this reaction was taken to indicate the occurrence of complete cleavage in the large-scale reaction (van der Ploeg and Flavell 1980). Restricted DNAs were fractionated on flat-bed agarose gels, transferred to nitrocellulose, and hybridized to a $\gamma$-globin gene-specific probe $3.3-\mathrm{kb}{ }^{\mathrm{A}} \gamma$-gene containing HindIII fragment) at $42^{\circ} \mathrm{C}$ in the presence of $50 \%$ formamide and $10 \%$ dextran sulfate, as described (Southern 1975; Maniatis et al. 1982). These probes were uniformly labeled by random priming, according to the methods of Feinberg and Vogelstein (1983). After 


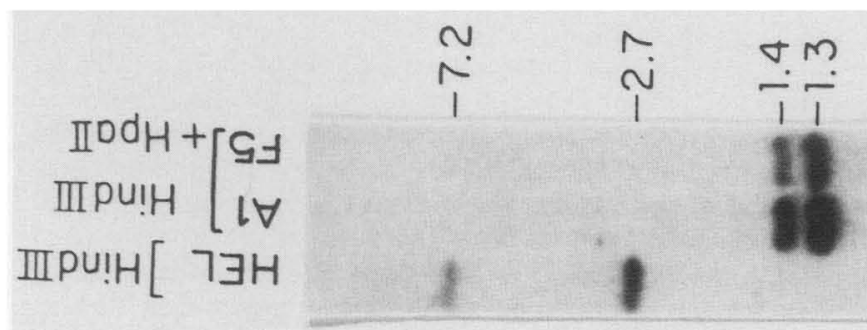

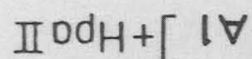 IHWOQ [G] $I d s w+[t \forall$ IHWDg $\left[\mathrm{SA}_{\exists}\right.$ IIOdH+ $\mathrm{LP}$ IY 003 G $S$}
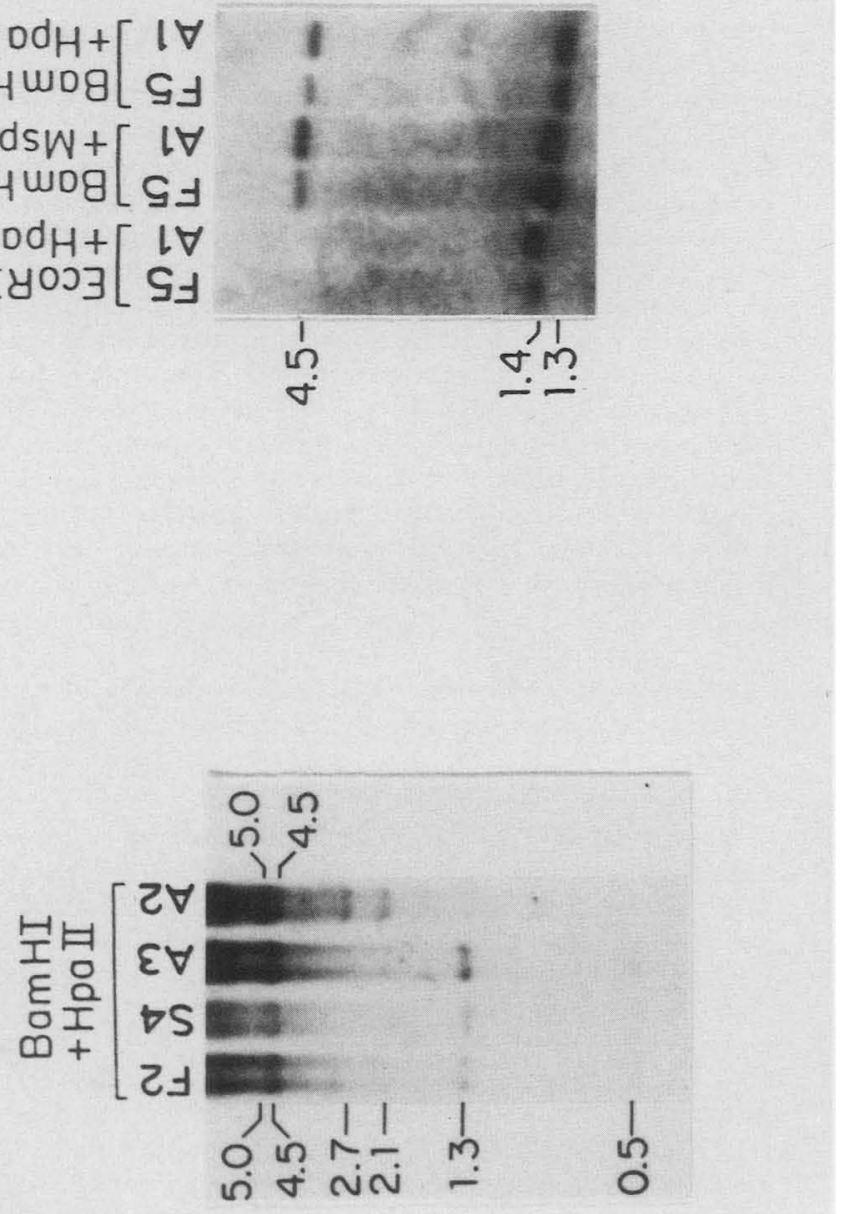

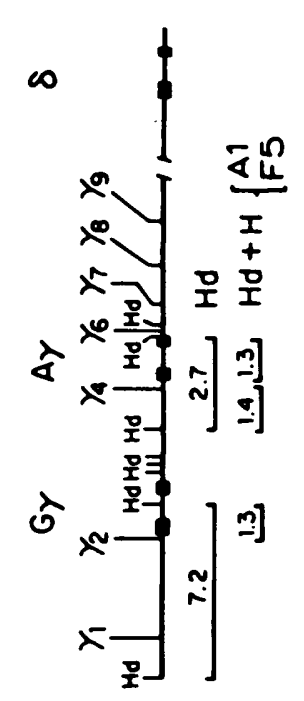

$\infty$
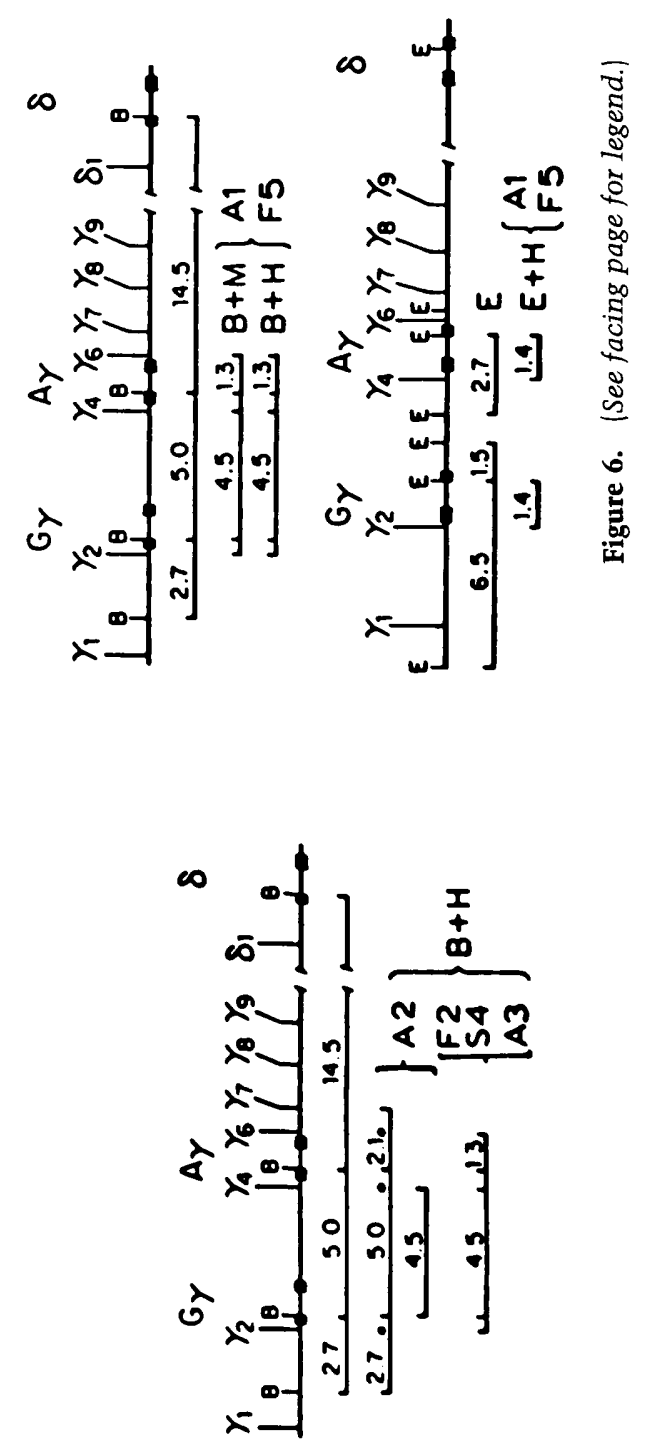
hybridization, filters were washed with several changes of $2 \times$ SSC at $65^{\circ} \mathrm{C}$, followed by two washes with $0.1 \times$ SSC at the same temperature.

\section{Acknowledgments}

We thank Martha Brice for assistance with tissue culture, and Doreen Loomans and Susan Quick for preparing the manuscript. This work was supported by a Cooley's Anemia Foundation award to T.E. and National Institutes of Health grants 5R01 HL2089 and 5R01 AM30852 to G.S. and T.P.

\section{References}

Bodine, D.M. and T.J. Ley. 1987. An enhancer element lies $3^{\prime}$ to the human Ay globin gene. EMBO J. 6: 2997-3004.

Boehm, T.L. and D. Drahovsky. 1981. Elevated transcriptional complexity and decrease in enzymatic DNA-methylation in cells treated with L-ethionine. Cancer Res. 41: 4101-4106.

Busslinger, M., J. Hurst, and R.A. Flavell. 1983. DNA methylation and globin gene expression. Cell 34: 197-206.

Christman, J., P. Price, L. Pedriman, and G. Acs. 1977. Correlation between hypomethylation of DNA and expression of globin genes in Friend erythroleukemia cell. Eur. I. Biochem. 81: 53-61.

Deisseroth, A. and D. Hendrick. 1979. Activation of phenotypic expression of human globin genes from nonerythroid cells by chromosome-dependent transfer to tetraploid mouse erythroleukemia cells. Proc. Natl. Acad. Sci. 76: 21852189.

Favaloro, J., R. Treisman, and R. Kamen. 1980. Transcription maps of polyoma virus-specific RNA: Analysis by two-dimensional nuclease $S 1$ gel mapping. Methods Enzymol. 65: $718-749$.

Feinberg, A.P. and B. Vogelstein. 1983. A technique for radiolabeling DNA restriction endonuclease fragments to high specific activity. Anal. Biochem. 132: 6-13.

Gartler, S.M., K.A. Deyer, J.A. Marshall Graves, and M. Rocchi. 1985. A two step model for mammalian $X$-chromosome inactivation. In Biochemistry and biology of DNA methylation (ed. G.L. Cantoni and A. Razin), pp. 223-235. A.R. Liss, Inc., New York.

Groudine, M., M. Peretz, B. Nakamoto, Th. Papayannopoulou, and G. Stamatoyannopoulos. 1986. The modulation of $\mathrm{Hb} \mathrm{F}$ synthesis in adult erythroid progenitor (burst forming unit) cultures reflects changes in $\gamma$-globin gene transcription and chromatin structure. Proc. Natl. Acad. Sci. 83: 6887-6891.

Jones, P.A. and S.M. Taylor. 1980. Cellular differentiation, cytidine analogs and DNA methylation. Cell 20: 85-93.

Kantor, J.A., P.H. Turner, and A.W. Nienhuis. 1980. Beta thalassemia: Mutations which affect processing of the $\beta$-globin mRNA precursor. Cell 21: 149-157.

Ley, T.J., N.P. Anagnou, G. Pepe, and A.W. Nienhuis. 1982. RNA processing errors in patients with $\beta$-thalassemia. Proc. Natl. Acad. Sci. 79: 4775-4779.

Ley, T.J., L.C. Yawen, D. Haidaris, N.P. Anagnou, V.L. Wilson, and W.F. Anderson. 1984. DNA methylation and regulation of the human $\beta$-globin-like genes in mouse erythroleukemia cells containing human chromosome 11. Proc. Natl. Acad. Sci. 81: 6618-6622.
Lock, L.F., N. Takagi, and G.R. Martin. 1987. Methylation of the Hprt gene on the inactive $\mathrm{X}$ occurs after chromosome inactivation. Cell 48: 39-46.

Maniatis, T., E.F. Fritsch, and J. Sambrook. 1982. Molecular cloning: A laboratory manual. Cold Spring Harbor Laboratory, Cold Spring Harbor, New York.

Mavilio, F., A. Giampolo, A. Care, G. Migliaccio, M. Calandrini, G. Russo, G.L. Pagliardi, G. Mastroberardino, M. Marinucci, and C. Peschle. 1983. Molecular mechanisms of human hemoglobin switching: Selective undermethylation and expression of globin genes in embryonic, fetal, and adult erythroblasts. Proc. Nat1. Acad. Sci. 80: 6907-6911.

McGhee, J.D. and G.D. Ginder. 1979. Specific DNA methylation sites in the vicinity of the chicken $\beta$-globin genes. $\mathrm{Na}$ ture 280: 419-420.

Melis, M., G. Demopulos, V. Najfeld, J-W. Zhang, M. Brice, Th. Papayannopoulou, and G. Stamatoyannopoulos. 1987. A chromosome 11-linked determinant controls fetal globin expression and the fetal-to-adult globin switch. Proc. Natl. Acad. Sci. 84: 8105-8109.

Monk, M. 1986. Methylation and the X chromosome. Bioessays 4: 204-208.

Murray, E.J. and F. Grosveld. 1987. Site specific demethylation in the human $\gamma$-globin gene does not alleviate methylation mediated suppression. EMBO I. 6: 2339-2335.

Niwa, O., Y. Yokota, H. Ishida, and T. Suguhara. 1983. Independent mechanisms involved in suppression of Moloney leukemia virus genome during differentiation of murine teratocarcinoma cells. Cell 32: 1105-1113.

Papayannopoulou. Th., M. Brice, and G. Stamatoyannopoulos. 1986. Analysis of human hemoglobin switching in MEL $\times$ human fetal erythroid cell hybrids. Cell 46: 469476.

Razin, A. 1984. DNA methylation patterns: Formation and biological functions. In DNA methylation, biochemistry and biological significance (ed. A. Razin, H. Cedar, and A.D. Riggs), pp. 127-146. Springer Verlag, New York.

Razin, A. and A.D. Riggs. 1980. DNA methylation and gene function. Science 210: 604-610.

Riggs, A.D. 1984. X-inactivation, DNA methylation and differentiation revisited. In DNA methylation: Biochemistry and biological significance (ed. A. Razin, H. Cedar, and A.D. Riggs| pp. 269-278. Springer Verlag, New York.

Shen, C.-K.J. 1984. DNA methylation and developmental regulation of eukaryotic globin gene transcription. In DNA methylation: Biochemistry and biological significance led. A. Razin, H. Cedar, and A.D. Riggs), pp. 249-268. SpringerVerlag, New York.

Shen, C.-K.J and T. Maniatis. 1980. Tissue specific DNA methylation in a cluster of rabbit $\beta$-like globin genes. Proc. Natl. Acad. Sci. 77: 6634-6638.

Shen, S., J.L. Slightom, and O. Smithies. 1981. A history of the human fetal globin gene duplication. Cell 26: 191-203.

Shepard, T.H., A.G. Fantel, and P.E. Mirkes. 1988. Collection and scientific use of human embryonic and fetal material: 25 years of experience In Issues and reviews in teratology (ed. H. Kalter) (in press).

Southern, E. 1975. Detection of specific sequences among DNA fragments separated by gel electrophoresis. I. Mol. Biol 98: 503-517.

Stamatoyannopoulos, G. and A.W Nienhuis. 1987. Hemoglobin

Figure 6. DNA methylation in adult phenotype subclones. DNAs from adult phenotype (A1-A3), switching phenotype (S4), and fetal phenotype (F2, F5) subclones were digested with the enzymes indicated. These samples were blotted and probed as described previously. 
switching In Molecular basis of blood diseases (ed. G. Stamatoyannopoulos, A.W. Nienhuis, P. Leder, and P.W. Majerus), pp. 66-93. W.B. Saunders Company, Philadelphia, Pennsylvania.

Stamatoyannopoulos, G., M. Farquhar, D. Lindsley, M. Brice, Th. Papayannopoulou, and P.E. Nute. 1983. Monoclonal antibodies specific for globin chains. Blood 61: 530-539.

van der Ploeg, L.H.T. and R.A. Flavell. 1980. DNA methylation in the $\gamma-\delta$ - $\beta$-globin locus in erythroid and nonerythroid tissues. Cell 19: 947-958.

Waalwijk, C. and R.A. Flavell. 1978. DNA methylation at a CCGG sequence in the large intron of the rabbit $\beta$ globin gene: Tissue specific variations. Nucleic Acids Res. 5: 4631-4641.

Weatherall, D.J. and J.B. Clegg. 1981. The thalassemia syndromes, pp. 49-72. Blackwell Scientific Publishers, Oxford, England.

Wood, W.G., J.B. Clegg, and D.J. Weatherall. 1977. Developmental biology of human hemoglobins. In Progress in hematology $X$ (ed. E.B. Brown), pp. 43-90. Grune and Stratton, New York.

Wysocki, L.J. and V.L. Sato. 1978. 'Panning' for lymphocytes: A method for cell selection. Proc. Natl. Acad. Sci. 75: 28442848. 


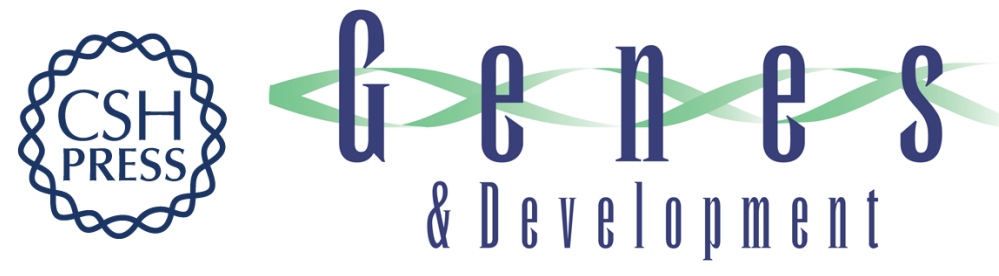

\section{DNA methylation: a secondary event in globin gene switching?}

T Enver, J W Zhang, T Papayannopoulou, et al.

Genes Dev. 1988, 2:

Access the most recent version at doi:10.1101/gad.2.6.698

\section{References This article cites 28 articles, 11 of which can be accessed free at:} http://genesdev.cshlp.org/content/2/6/698.full.html\#ref-list-1

\section{License}

Email Alerting

Receive free email alerts when new articles cite this article - sign up in the box at the top Service right corner of the article or click here.

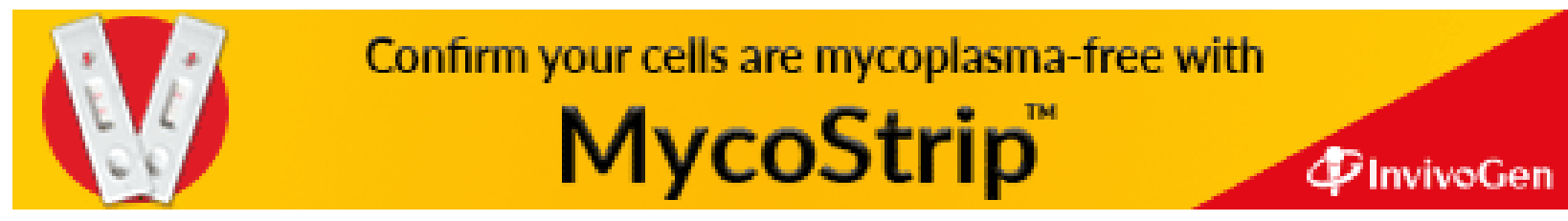

